\title{
Students' Public Speaking Assessment for Persuasive Speech
}

\author{
Pipit Rahayu $^{1 *}$, Yenni Rozimela ${ }^{2}$, and Jufrizal Jufrizal ${ }^{3}$
}

\author{
${ }^{1}$ English Department, Pasir Pengaraian University \\ ${ }^{2}$ Universitas Negeri Padang \\ ${ }^{3}$ Universitas Negeri Padang \\ *Corresponding author. Email: darariau2010@gmail.com
}

\begin{abstract}
Public Speaking is an academic necessary for University Students. Public speaking is the process of giving the information, persuading the audience or attracting the hearers. This Paper reports the findings drawn from thirdsemester students' skill in public speaking. The aims of this study were to reveal the extent of students' skill in persuasive speech. Data were obtained from students' public speaking test of 29 English students and analyzed and described in qualitatively. The finding came up with encouraging result where greater proportion of the samples reported significant number in good level of categories in persuasive skill. There was $51,72 \%$ of students was in good level of accent, grammar, vocabulary, fluency, and Comprehension. Moreover, it could be noted that the highest score of students' skill was in vocabulary bad comprehension aspect in rating scale. In short, students' skill to change the habit, costume and social communication of others for a persuasive speech is already achieved.
\end{abstract}

Keywords: Public Speaking, Persuasive Speech, Assessment

\section{INTRODUCTION}

In higher education, public speaking skill is an important thing. Public speaking is needed as one of the most academic necessary skills for the high level students [1]. Public speaking is the process of giving the information, persuading the audience or attracting the hearers [2]. In other words, Public Speaking is an activity of presenting and sending a message from a speaker to a specific hearer.

In line with this, Public speaking should be considered in presenting the speech. Linked with this, it is needed a planning and organizing the material of the speech [3]. Furthermore, there are three types of public speaking based on the content of the speech: the informative, persuasive, and entertainment. The usual kinds of public speaking are informative and persuasive. However, informative speech is arranged to share knowledge between the speakers and audiences [4]. It can be found in the in the classroom, in this case, the lecturers give their knowledge with the students. Then, Persuasive speaking is the content of the speech try to persuade the audience. In addition, persuasive speech gives the argumentation to motivate, and bring the audience's mind to get better. Then, entertainment

Speaking is describing some activities such as announcing and receiving awards, delivering wedding party and memorizing the excellent services of dinner speech [5]. It means that verbal and nonverbal skills were important in public speaking.

Due to the importance of public speaking skill, assessment of students learning outcomes is also essential part in higher education and will be the key point to get the students' achievement especially improving their skills [6]. In this case, the main goal of assessment is to get the comparison in improving students' knowledge, behaviors and attitudes [7;8;9]. Furthermore, assessment provides the lecturers give the specifics method especially in teaching and learning activities and institutions program [10].

In English Department at the Pasir Pengaraian University, students will learn public speaking at third semester in speaking III subject. In this class, the students are required to fulfill their previous subject, speaking I and speaking II. The goal of speaking III subject in English study program is to prepare the students to be proficient in delivering English speech. There are many types of speech are taught in speaking III subject, for example impromptu speech, informative speech, and persuasive speech. However, many students still have difficulties in delivering the speech, especially persuasive speech. It is caused by various factors, likes less of practice in making speeches or they don't have more understanding about persuasive speech in detail. They think that all of speeches have same content and 
values. In fact, each of speeches has different material, topics and the way in delivering.

\section{REVIEW OF RELATED LITERATURE 2.1 PUBLIC SPEAKING ASSESMENT}

Generally, there is the different between the student who has gotten the training of public speaking and the students never take the public speaking training in public speaking class[11]. It can be seen that students feel enjoy to communicate and practice in the classroom. So, it will be a consideration, public speaking is academic importance in improving students' communication abilities [12]. Furthermore, there is the impact of getting more knowledge of public speaking. In assessing students' skill, lecturers' feedback is the most important thing to know the strength and weaknesses as long as the studying process. Feedback is the integration part of the formative assessment and helps to determine what has been achieved and what the next goal is in terms of learning. According to [13] feedback is the information from the lecturer to students on the correctness of their work and how to further improve the work. The feedback sandwich method is a popular method of giving construct a positive response of language learning. In addition, feedback had an impact to speaking performance as a tool of the measurement of the students' weaknesses [14].

Nowadays, technology has the important plays in managing in developing language classrooms and it will be a assistant in serving the teachers in teaching and learning activities [15]. The development of web-based assessment will result good assessment instrument, it will provide benefits for lecturer and student, for example it can determine the level of students' achievement in learning of actual information. Webbased assessment should fit in with and help to achieve the course aims. Web-based gives the chance to open the interaction between lecturers and students. It is an effort that could be made to persuade students to follow the learning process.

Furthermore, the web-based assessment is one solution that will be integrated the curriculum and learning process [16]. Web-based assessment will give the accuracy assessment forms [17]. The practicality of this assessment are (a) improving of learning instruction; (b) providing the feedback for the students that give the contribution in teaching model used or strategies of teaching and changing the students' habit and attitudes in leaning process [18].

The Public Speaking Competence Rubric was other instruments that will be considered as evaluation of the speaker's competence. This evaluation covers the competence of the Speaker that measure and score oral communication and the behavior speakers [19]; [20]. The PSCR is used to evaluate adult public speaking competencies especially higher education level. This instrument is also used a holistic score in public speaking depend on the appropriate activities in delivering the speech [21]. It is known as a neutral assessment because it a global instrument of public speaking.

\subsection{PERSUASIVE SPEECH}

Persuade is to bring others opinions to follow the speakers' intention. The main aims is to change the attitudes, habits, mind and view of the audiences. In addition, the bad impact of this is modifying the mindset of the hearers [22]. Besides, it sometimes provokes the other one to do the bad actions or to support what the speakers'. In other words, it can be said there is the changing opinion after getting the main point of the [23]. In this case, there is the advantage of this speech in one group to increase the company or their career and giving the inspiration.

Furthermore, persuasion speech is an icon activity in which the speakers want to invite other people to elaborate their mind-set or behavior toward an something through the movement of a views, in an area of many solutions [24]. In line with this, it will involve information, such as informative speech [25], the key difference is the word "change". The formula is "Information + Change $=$ Persuasion". It means that the information that will be used in the presentation for changing something about the audience members and possibly environment, based on their responses. In addition, a persuasive speech will make to rearrange or their hearers' habit, costume, desire, or mind set in order to do something different [26].

Besides, persuasive speaking try to change and rearrange the audiences' beliefs, attitudes, values, and their behaviors [27]. To convince the audience, a speakers have to build the real fact or the real event by claiming data, giving evidence, and warranting data [28]. The claim is the argument/statement that is followed the real evidence. Furthermore, the persuasive speech is a speech that convinces the audience by doing everything to invite the audiences' mind to do what the speakers' wants. Of course, the process of speech is followed with the suitable body language, loud and clear tone, and the sense of the emotion [29]. In short, persuasive speech is to order someone to do something by giving the real evidence. Thus, it needs an approach to make closer between the speakers and the listener in order to fulfill the messages of the speech.

In Addition, persuasive speaking provides the concept of the speakers about the topic used and threats the listeners to do something [29]. In this case, the speaker deliver the speech by giving the advantages and disadvantages to audiences logically and order the audiences do something. In other words, persuasion is the art of the speech to bring the other's mind set and make it more comfortable doing it [30]. Furthermore, persuasive speaking serves the speech that need to changing the audiences' emotional, costume and habit in circumstances of the speakers' desire.

In addition, the persuasive speech is the competence of the speakers to influence the mind-set of the audiences as well as the audiences feel stand up in the speakers' position. It means that there is the 
combination opinion of speakers and audiences in same concept or fact [31]. The impact can be process or the changing audience's impressions, opinions or most ambitiously. In addition, the content of the persuasive speaking can be a claiming or presenting the policy [32]. So, it can be concluded that he aims of a persuasive speech is to bring the hearer's opinion to do something. Furthermore, there are three basic parts of persuasive speech [33]:

1. Ethos (The speaker' intention to influence the audience)

2. Logos (the logic of speakers' intention or messages)

3. Pathis (the ability of the evidence to link the speakers and audiences)

\section{METHOD}

\subsection{Research Design}

This study was a descriptive quantitative research. In addition, research design is organized to obtain the data with the circumstances pointed [34]. Meanwhile, the model of study design used in this part is quantitative. Furthermore, quantitative research is a investigating the data for testing objective theories or event by measuring the variables of the research [35]. The variables of data will be analyzed by using SPSS or can be said by statically analysis.

\subsection{Setting of the Research}

This research would be recognized at Third Level of students of English Department at Pasir Pengaraian University. It was located Rambah Hilir, Rokan Hulu. The research would be held from December 2020 to May 2021.

\subsection{Population and Sample}

Population is the total region that consist of object that have and certain characteristic who determined by researcher to be learned and to be investigated [36]. The number of the data of this research was the third semester English Students University of Pasir Pengaraian, academic year 2020/2021. There were 29 students and all of students would be population. Based on the considerations above, the researcher used probability sampling means that sampling technique where the the number of samples is the same as the population. The sample that should have been in this research was 29 samples. So in this research, the amount of samples is the same as the population, they were 29 person.

\subsection{Instrumentation of the Research}

The type instrument of the research is speaking test. The test was given to the students to deliver in persuasive speech. Then, students' speaking test would be analyzed by scoring rubric of persuasive speech. The scoring rubric was taken from Hughes's theory [37].

\subsection{Technique of Collecting the Data}

There are some techniques of collecting the data as follow as:

a. The researcher gave the speaking test for students that consist of instructions deliver persuasive speech

b. The students prepared one topic that they have Chosen.

c. Students delivered persuasive speech. The maximum time given is seven minutes.

d. The researcher recorded the videos from the students.

\section{RESULT}

There were five components of the speaking that would be measured in this article. The data could be showed the following explanation.

\subsection{Students' Accent}

The students' skill in terms of accent is shown in the below data:

Table 1. The data of the students' accent

\begin{tabular}{|c|c|c|c|c|}
\hline No & Score & Level & Frequency & Percentage \\
\hline 1 & $81-100$ & Excellent & - & - \\
\hline 2 & $61-80$ & Good & 3 & $10,34 \%$ \\
\hline 3 & $41-60$ & Average & 23 & $79,31 \%$ \\
\hline 4 & $21-40$ & Fair & 3 & $10,34 \%$ \\
\hline 5 & $0-20$ & Poor & - & - \\
\hline \multicolumn{3}{|c|}{ Total } & 29 & $100 \%$ \\
\hline
\end{tabular}

Based on the data 1, it could be found that the students skill in accent have variety level of frequency point because 3 student $(10,34 \%)$ were in good level . their range between 61-80. It means that there is a mistake in pronunciation. The students had delivered speech in good, but they could not said as a native speaker. This case can be seen when students delivered the speech, they need more pace and clarity. The second, 23 students $(79,31 \%)$ were average in accent because they got the score in range between 41-60. It means that they had "Foreign accent" requires concentrated listening and mispronunciations lead to occasional misunderstanding. This case can be seen in their pronunciation. For example they said the word "prophet ", but they pronounce "propet"and it should be pronounce "/'profit/." .The last, 3 students $(10,34 \%)$ were fair or they got the score between $21-40$, it means that they had low score and the accent was heavy spelling. This case can be seen when they say the word "about", they pronounced "abot",it should be "/a'bavt/", the word "caused" was pronounced "kauset",it should be " $/ \mathrm{ko:z/}$ ". Another case can be seen when they deliver speech, they say the word "eeeeee" between the words. Based on the description above, it was clear that most students were in average level, a litle students had fair, and a litle students had good level. Many students were wrong in their spoken or they did mispronunciation. 


\subsection{Students' Grammar}

The students' skill in terms of accent is shown in the description as follows:

Table 2. The description of the students' Grammar

\begin{tabular}{|c|c|c|c|c|}
\hline No & Range & Level & $\begin{array}{c}\text { Frequ } \\
\text { ency }\end{array}$ & $\begin{array}{c}\text { Percent } \\
\text { age }\end{array}$ \\
\hline 1 & $81-100$ & Excellent & 2 & $6,89 \%$ \\
\hline 2 & $61-80$ & Good & 12 & $41,37 \%$ \\
\hline 3 & $41-60$ & Average & 14 & $48,27 \%$ \\
\hline 4 & $21-40$ & Fair & 1 & $3,44 \%$ \\
\hline 5 & $0-20$ & Poor & - & - \\
\hline \multicolumn{3}{|c|}{ Total } & 29 & $100 \%$ \\
\hline
\end{tabular}

Based on the table 5, it was clear that there were 2 students $(6,89 \%)$ got the excellent level because their range is in 81-100, it means that there were a few error or mistakes. In other hands, 12 student $(41,37 \%)$ were in good because they in range $61-80$, it is mean that there were the weaknesses in grammar. And then, 14 students $(48,27 \%)$ were in average because they in range $41-60$, it means that there were a half frequent errors in speaking. This case can be seen in their tenses error, for example they made "...The internet has become...". This sentence should be "...The internet has became...". Another case can be seen at the sentence structure "...We all know when we are sick..." ,it should be "...All of us know when we are sick..." . The last, there is 1 student $(3,44 \%)$ were in fair because they in range $21-40$, it means that there were much errors in showing control of speech.

Based on the data above, it was clear that the students in grammar still in average level. The students were in average more than the good and excellent because the students still low in grammar. They did a mistake when they produce the sentence. They did not good use tenses and then they always did mistake to put the structure in their sentence; they should prepare and correct their script.

\subsection{Students' Vocabulary}

The students' skill in terms of accent is shown in the description as follows:

Table 3. The description of the students' Vocabulary

\begin{tabular}{|c|c|c|c|c|}
\hline No & Range & Level & $\begin{array}{c}\text { Frequen } \\
\text { cy }\end{array}$ & $\begin{array}{c}\text { Percenta } \\
\text { ge }\end{array}$ \\
\hline 1 & $81-100$ & Excellent & 13 & $44,82 \%$ \\
\hline 2 & $61-80$ & Good & 15 & $51,72 \%$ \\
\hline 3 & $41-60$ & Average & 1 & $3,44 \%$ \\
\hline 4 & $21-40$ & Fair & & \\
\hline 5 & $0-20$ & Poor & - & - \\
\hline \multicolumn{3}{|c|}{ Total } & 29 & $100 \%$ \\
\hline
\end{tabular}

Based on the table 6, Most of students are in good level. We can see that there are some students in excellent level about 13 students $(44,82 \%)$ between 81 100 or they had made Professional vocabulary broad and precise. This case can be seen when the students delivered the speech about environment protection, it was made supporting vocabulary such as the scope of cleanliness, greening, and other varied vocabulary. There are 15 students $(51,72 \%)$ were in good level between $61-80$. They had made general vocabulary permits discussion. This case can be seen that the students have made vocabulary related to the topic. For example, when the students delivered the speech about the benefit of blood, they made the general vocabularies of the topic. They are only 1 student $(3,44 \%)$ were in average level. The student had limitations of vocabulary prevent discussion of some social topic. It can be shown that the topics presented did not cover the entire material, so the vocabulary only struggled in one discussion and the vocabulary is not various. They should add their vocabulary for mastery in their speaking skill. From the explanation above, the students' vocabulary were in good level.

\subsection{Students' Fluency}

The students' skill in terms of accent is shown in the following table:

Table 4. The analysis on the students' Fluency

\begin{tabular}{|c|c|c|c|c|}
\hline No & Range & Level & $\begin{array}{c}\text { Frequen } \\
\text { cy }\end{array}$ & $\begin{array}{c}\text { Percent } \\
\text { age }\end{array}$ \\
\hline 1 & $81-100$ & Excellent & 1 & $3,44 \%$ \\
\hline 2 & $61-80$ & Good & 8 & $27,58 \%$ \\
\hline 3 & $41-60$ & Average & 11 & $37,93 \%$ \\
\hline 4 & $21-40$ & Fair & 9 & $31,03 \%$ \\
\hline 5 & $0-20$ & Poor & - & - \\
\hline \multicolumn{3}{|c|}{ Total } & 29 & $100 \%$ \\
\hline
\end{tabular}

About 11 students $(37,27 \%)$ were average. It means that the students still got the weaknesses in fluency. This case can be seen when they delivered one sentence has not been completed; it will be continued with another sentence. So, that it becomes ambiguous speech. The table shows that 1 student $(3,44 \%)$ was excellent in fluency, or they delivered the speech smoothly. In this case, they delivered speeches well and fluently, just not exactly like natives. About 8 students $(27,58 \%)$ were good in fluency. They delivered speeches by repetition a few words to sentences frequently caused by nervous. The last 9 students $(31,03$ $\%$ ) were in fair or they had speech is very slow. In this case, the students have the limited ideas and vocabulary, so the sentences are simple and underdeveloped. In addition, students spoken slowly, they look like remember their script and many students always silent for a moment; sometimes they said "eee". From the explanation above, the conclusion is students' skill in fluency aspect were still average. The students were very slow in speech because what the students deliver, it is still confuse and the students had limited idea to be developed.

\subsection{Students' Comprehension}

The students' skill in terms of accent is shown in the following table: 
Table 5. The analysis on the students' comprehension

\begin{tabular}{|c|c|c|c|c|}
\hline No & Range & Level & $\begin{array}{c}\text { Frequen } \\
\text { cy }\end{array}$ & $\begin{array}{c}\text { Percenta } \\
\text { ge }\end{array}$ \\
\hline 1 & $81-100$ & Excellent & 12 & $41,37 \%$ \\
\hline 2 & $61-80$ & Good & 15 & $51,72 \%$ \\
\hline 3 & $41-60$ & Average & 2 & $6,89 \%$ \\
\hline 4 & $21-40$ & Fair & - & \\
\hline 5 & $0-20$ & Poor & - & - \\
\hline \multicolumn{3}{|c|}{ Total } & 29 & $100 \%$ \\
\hline
\end{tabular}

Based on the description above, 12 students ( $41,37 \%$ ) were in excellent in comprehending the topic or they understands everything such as formal and nonformal speech. Secondly, there are 15 students $(51,72$ $\%)$ were in good comprehend the topic. The last, there are 2 students $(6,89 \%)$ were in average or they did not deliver a speech. This case can be shown when the students deliver speeches, they avoid the dialogue or communication to the audience and they repeat the sentences frequently. It was caused they did not comprehend deeply about their material. Based on the description, it was clear that the students' level in comprehension aspect was good level. It is caused by their understanding about the topic.

After explaining each of aspect in delivering persuasive speech, researcher wants to make conclusion of level from each aspect. The conclusion was viewed on the description below.

Table 6. The result of students' speech by three raters

\begin{tabular}{|c|c|c|c|}
\hline No & Indicators & Percentage & Level \\
\hline $\mathbf{1}$ & Accent & $50,29 \%$ & Average \\
\hline $\mathbf{2}$ & Grammar & $59,08 \%$ & Average \\
\hline $\mathbf{3}$ & Vocabulary & $79,66 \%$ & Good \\
\hline $\mathbf{4}$ & Fluency & $53,68 \%$ & Average \\
\hline $\mathbf{5}$ & Comprehension & $79,44 \%$ & Good \\
\hline
\end{tabular}

Based on the description 10, it can be found that the percentage of each aspect. The data collected from 29 students of third level of English Department at University of Pasir Pengaraian. The students' accent is $50,29 \%$, students' grammar is $59,08 \%$, students' vocabulary is $79,66 \%$, students' fluency is 53,68 , and students' comprehension is $79,44 \%$.

\subsection{Result of students in delivering persuasive speech}

The result of the students' persuasive speech by three raters of all aspects can be seen in the following table 7. Based on the description 7, the percentage of students has the result that the students were in average level. From the explanation, it could be found that most of the students were in average. It means that the third level students of English Department at university of Pasir Pengaraian had average in delivering persuasive speech. 2 students were in excellent score, 15 students were the good score, and 12 students were in average score. In conclusion, the table above shows that the students skill in delivering persuasive speech was in good level $(64,43 \%)$.

Table 7. The Result of Students' skill in Delivering Persuasive Speech

\begin{tabular}{|c|c|c|c|c|}
\hline No & Range & Level & $\begin{array}{c}\text { Frequ } \\
\text { ency }\end{array}$ & Percentage \\
\hline 1 & $81-100$ & Excellent & 2 & $6,89 \%$ \\
\hline 2 & $61-80$ & Good & 15 & $51,72 \%$ \\
\hline 3 & $41-60$ & Average & 12 & $41,37 \%$ \\
\hline 4 & $21-40$ & Fair & - & - \\
\hline 5 & $0-20$ & Poor & - & - \\
\hline \multicolumn{3}{|c|}{ Total } & 29 & $100 \%$ \\
\hline
\end{tabular}

From the data in the table of result the students in delivering persuasive speech, the researcher concluded that the students' speaking skill in delivering persuasive speech is in good score. There are 2 students categorized in excellent level $(6,89 \%)$, there are 15 students got good level( $51,72 \%)$, and there are 12 students got average level ( 41,37).

\section{DISCUSSION}

There were five aspect in assessing students' speech included accent, grammar, vocabulary, fluency, and comprehension [37]. In addition, the research result presented that the students were in good level in all of aspect. After getting the data, the researcher needed to discuss the findings to result of the question of the study.

From the findings, it concluded that students' skill in persuasive speech at third level students English Department at University of Pasir Pengaraian. The data showed that the score $64,43 \%$ that categorized in good level. The research also found the result of each aspect. It was consist of accent, grammar, vocabulary, fluency, and comprehension. The score of accent was 50,29\% that categorized in average level, grammar 59,08\% in average level, vocabulary $79,66 \%$ in good level, fluency $53,68 \%$ in average level, and comprehension $79,44 \%$ in good level.

The finding show that students' accent categorized in average level $(50,29 \%)$. It means that they had "Foreign accent". This case could be seen in the pronunciation. The students were difficult to pronounce word in English [37]. The vocabulary is important things because it will be impossible to speak up without various words.

The score of grammar was 59,08. This result showed that students' grammar were still in average. This finding was supported by [38] stated that it will be complicated problem for learner to proof when they were taught by the teachers; they still confused about the topic and did not know what should be said.

The score of fluently was $53,68 \%$. It was in average level. In this case, there was a weakness about teaching English. It is to make the students using language effectively and correctly in communication 
[39]. However, it seems that students were not able to talk fluently and accurately because they do not have enough knowledge about the subject. Most of the students delivered a speech incompletely.

From the discussion above, the students still have difficulties in accent, grammar, and fluency aspect. Most of the students were difficult in accent aspect because the students had mispronunciation or the students were difficult in pronouncing word in English. Most of the students were difficult in grammar aspect because the students had made some errors that showing some mistakes in controlling the sentences' pattern. In addition, most of the students were difficult in part of fluency because the students were difficult in describing the topic given because they have lack of ideas. However, students' skills in vocabulary and comprehension aspect were in good level. It could be proven that the students' score were good in vocabulary and comprehension aspect. In addition, the explanation above, the researcher concluded that the students 'skill were good in delivering persuasive speech.

\section{CONCLUSION}

The researcher did the research about the students' speaking skill in delivering persuasive speech. The researcher used spoken test and video recording to see the students' speaking skill in delivering Persuasive speech of the 3 level students English Department at University of Pasir Pengaraian. Based on the finding and discussion, the researcher concluded that students' speaking skill in delivering persuasive speech at the 3 level students of English Department was in good level. From the five aspects, the students were good in vocabulary and comprehension. The students' vocabulary was categorized in good level. The students' comprehension also was categorized in good level.

\section{REFERENCES}

[1] Backlund, P., \& Morreale, S. . P. (1994). History of the speech communication association's assessment efforts and present role of the committee on assessment and testing. In \& C. C. S. Morreale, M. Books, R. Berko (Ed.), SCA summer conference proceedings and prepared remarks (p. 9016). Annandale, VA: Speech Communication Association Publications.

[2] Backlund, P., \& Arneson, P. (2000). Educational assessment grows up: Looking toward the future. Journal of the Association for Communication Administration, 29, 88-102.

[3] Gareis, E. (2006). Guidlines for public speaking. New York: Baruch College.

[4] Graside, C. (2002). Seeing the forest through the trees: A challange facing communication across the curriculum programs. Communication Education, 51(1), 51-64.

[5] Hickerson, C. (2006). Scoring rubric for oral communication behavior assessment. Hairrisburg, VA: James Madison University.

[6] Kulm, J. (1994). Mathematics assessment: What works in the classroom? San Francisco, CA: Jossey-Bass.

[7] LeBlanc, K., Vela, L., \& Houser, M. L. (2011). Improving the basic communication course: Assessing the core components. Basic Communication Course Annual, 23, 61-92.

[8] Lucas, S. E. (2015). The art of public speaking (12thEd.). New York: McGraw Hill.

[9] Morreale, S. P., \& Pearson, J. C. (2008). Why communication education is important: The centrality of the discipline in the 21 st century. Communication Education, 57, 227-240.

[10] Neale. (2007). Speechwriting in perspective: A brief guide to effective and persuasive communication. Congressional Redearcch Service.

[11] Nikitina, A. (2011). Successful public speaking. Arina Nikitina \& Ventus Publishing.

[12] Novakovic, N., \& Teodosijevic, B. (2017). Basic public speaking. Journal of Economics, Management and Informatics, 8(2), 36-46.

[13] Ovanda, M. N. (1992). Constructive feedback: A key to successful teaching and learning.

[14] O'hair. (2010). A pocket guide to public speaking (3th Ed.). Boston.

[15] Osborn, M., \& Osborn, S. (1991). Public Speaking (2nd ed). Boston: Houghton Mifflin.

[16] Pearson, J., Godinho, S. A., Tavares, A., \& Glover, D. M. (2006). Heterologous expression of mammalian Pik1 in Drosophila reveals divergence from Polo during late mitosis. Exp. Cell. Res., 312(6), 770-780.

[17] Perloff's, R. M. (2013). The dynamics of persuasion: communication and attitudes in the 21 st century (2nd ed). Lawrence Eribaum Assiciates Publishers.

[18] Schmitz, A. (2012). A primer on communication studies.

[19] Schreiber, L., \& Hartanft, M. (2013). Introduction to public speaking.

[20] Schreiber, L. M., Paul, G. D., \& Shibley, L. R. (2012). The development and test of the public speaking competence rubric. Communication Education, 61(3), 205-233.

[21] Sun, Y. C., \& Yang, F. Y. (2015). I help, therefore, I learn: service learning on Web 2.0 in an EFL speaking class. Computer Assisted Language Learning, 28(3), 202-219.

[22] Templeton, M., \& Fitzgerald, S. S. (1999). Schaum's quick guide to great presentations. New York: McGraw-Hill.

[23] Tucker, B. (2018). Exploring public speaking (3rd Ed.). Georgia: GALILEO Open Learning Materials.

[24] Webster, J. L. (2012). Introduction to public speaking (2nd ed). Shreveport: Louisiana State University.

[25] Wrench, J. S., Goding, A., Johnson, D. I., \& Attias, B. A. (2012a). Public speaking: Practice and ethics. 
[26] Wrench, J. S., Goding, A., Johnson, D. I., \& Attias, B. A. (2012b). Public speaking: Practice and ethics.

[27] Xiao, J., Wang, Z., \& He, L. (2005). Exploring an integrated approach to web based course assessment. Asian Association of Open Universities Journal, 1(1), 38-44.

[28] Mapes, M. (2019). Speak Out, Call In: Public Speaking As Advocacy. Pressbooks.

[29] Schmitz, A. (2012). A primer on communication studies.

[30] Osborn, M., \& Osborn, S. (1997). Public speaking (4th ed.). Boston: Houghton Mifflin Company.

[31] Neale, T. H. (2011). Speechwriting in Perspective: A Brief Guide to Effective and Persuasive Communication. DIANE Publishing.

[32] Marteney, J. (2020). ARGUING USING CRITICAL THINKING. Los Angeles Valley College: LibreTexts.

[33] O'Quinn, K. (2009). The Elements of Persuasion: Three principles that will strengthen any appeal. SO01 Public Relations Tactics.

[34] Lexy J. Moleong, Metode penelitian Kualitatif, cet ke 2, (Bandung: Remaja Rosdakarya, 2006), hal. 9

[35] Apuke, O. D. (2017). Quantitative Research Methods : A Synopsis Approach. Kuwait Chapter of Arabian Journal of Business and Management Review.

[36] Sugiyono. 2011. Metode Penelitian Kuantitatif, Kualitatif dan R\&D. Bandung: Afabeta

[37 Hughes, Arthur. 2003. Testing for Language Teachers. Cambridge: Cambridge University Press.]

[38] Leong, L.-M. (2017). An Analysis of Factors Influencing Learners' English Speaking Skill. International Journal of Research in English Education, 34-41

[39] Davies, P., \& Pearse, E. (2000). Success in English Teaching. Oxford University Press. 